\title{
EFFECTS OF DIFFERENT IRRIGATION LEVELS AND PROLINE TREATMENTS ON ORGANIC ACIDS AND SECONDARY METABOLITES OF PEPPER (Capsicum annuum L. cv. Yalova Yağlık 28)
}

\author{
SARIYER, T. - ÖZTOKAT KUZUCU, C. \\ Department of Horticulture, Faculty of Agriculture, Çanakkale Onsekiz Mart University \\ Çanakkale Turkey \\ *Corresponding author \\ e-mail: cananoztokat@yahoo.com; phone: +902862180018/1387; fax: +90-286-218-0545
}

(Received $30^{\text {th }}$ Nov 2018; accepted $4^{\text {th }}$ Feb 2019)

\begin{abstract}
Pepper is quite sensitive to water stress, thus changes in irrigation levels may have significant effects on yield, organic acids and phenolics of peppers. Improper irrigation levels may generate a water stress and resultant stress then create serious oxidative damages on cell membranes. Such damages can be prevented with proline-like antioxidative substances. This study was conducted in Çanakkale - Turkey to investigate the effects of different irrigation levels and proline treatments on yields, quality parameters and organic acid composition of pepper (Capsicum апnиum L. cv. Yalova Yağlik 28) in the years of 2013 and 2014. Experiments were conducted in randomized blocks split plots experimental design with 3 replications. Three different irrigation levels were arranged as to apply certain percentages of total evaporation from Class-A pan $\left(\mathrm{Kcp}_{50}, \mathrm{Kcp}_{100}, \mathrm{Kcp}_{150}\right)$. Proline treatments $(12 \mathrm{mM})$ were applied at 3 different growth stages (three equal portions on 20,30 and $40^{\text {th }}$ days, single treatment on $30^{\text {th }}$ day and single treatment on $40^{\text {th }}$ day of growth). In both years of the experiments, decreasing citric acid contents and increasing ascorbic acid contents (in the first year of experiments, $\mathrm{Kcp}_{50}=84.54$, $\mathrm{Kcp}_{100}=175.48$, $\mathrm{Kcp}_{150}=198.92 \mathrm{mg} / 100 \mathrm{~g}$ ) were observed with increasing irrigation levels. Different irrigation levels and proline treatments had significant effects on yield $\left(\mathrm{g} / \mathrm{m}^{2}\right)$, total phenolics $(\mathrm{mg} / 100 \mathrm{~g})$, soluble solids content (SSC, \%) and internal proline content $(\mu \mathrm{mol} / \mathrm{g})$ of pepper fruits. Adversely affected parameters as yield $\left(\mathrm{g} / \mathrm{m}^{2}\right)$ and ascorbic acid content due to limited irrigation positively affected with some proline treatments.
\end{abstract}

Keywords: Industrial pepper, water stress, ascorbic acid, citric acid, total soluble solids

\section{Introduction}

Besides fresh consumption, capia peppers are also produced for industrial purposes (pepper paste, canned food). They are also called oil-pepper. Since pepper is quite sensitive to water stress, irrigation plays a significant role in pepper production. Pepper roots are quite sensitive to excess water; therefore, sufficient moisture should continuously be available at root zone (Campos et al., 2014; Penella et al., 2014; Vural et al., 2000).

As a cellular adaptation mechanism to water deficits, plants try to preserve proper water potential and cell turgor through accumulation of dissolved osmolites including proline (Bray, 1997). Proline is accumulated as a response to different stress conditions. It is also mentioned as an osmolite and free-radical (reactive oxygen species) scavenger (Reddy et al., 2004; Trovato, 2008).

In previous studies on different irrigation levels (Erken, 2012; Korkmaz et al., 2015), significant increases were reported in proline contents with decreasing irrigation levels. Reactive oxygen species serve as signaling molecules under normal conditions, but they create oxidative damages on stress-exerted cells (Sharma et al., 2012). Proline then 
emerges as a non-enzymatic antioxidant able to prevent such oxidative damage (Gill and Tuteja, 2010).

Under deficit moisture or water stress conditions, reactive oxygen species generate damages especially on cell membranes where lipids are concentrated. For instance, hydroxyl radicals attack polyunsaturated fatty acids sensitive to peroxidation and initiate lipid peroxidation (Gutteridge, 1995). It was indicated in previous studies that external proline treatments prevented stress-induced negative conditions (Silva $\mathrm{Sa}$ et al., 2016; Öztekin, 2009).

Pepper is quite a significant vegetable for our country's economy. Health impacts of antioxidant compounds, ascorbic acid, carotenoids and phenolics of the peppers were pointed out in previous studies (Howard et al., 2000; Marin et al., 2004)

Secondary metabolites are structurally and chemically different from the primary metabolites like sugar, fatty acids, amino acids and nucleic acids. They are not directly needed for basic photosynthesis and respiration metabolisms, but are considered as compounds encountered in specialized cells required for plants to stay alive. Phenolics are the most common secondary metabolites encountered in plants and they play significant roles in various physiological processes in plants (Balasundram et al., 2006; Lattanzio et al., 2006; Nascimento and Fett-Neto, 2010). Several stress factors including high light intensity, low temperature, pathogen infections, mineral deficiency, UV radiation and negative moisture regime may increase the production of free radicals and the other oxidative species. Plant phenolics play important roles as defense compounds against such stressors moreover biotic and abiotic stressors were reported to stimulate the production of secondary metabolites (Chanishvili et al., 2007). Arnnok et al. (2012) reported total phenolics in pericarp section of paprika peppers (Capsicum annuum L.) as between 0.782-4.52 $\mathrm{g} \mathrm{GAE} \mathrm{kg}^{-1}$ fresh weight.

Peppers are quite rich in ascorbic acid and several health benefits of ascorbic acid were reported in previous studies (Pereira et al. 2009; Li and Schellhorn, 2007; Siddique, 2006; Carr and Frei, 1999). Citric acid is an organic acid and used in canned foods and other food processing industries to reduce $\mathrm{pH}$ levels, heat requirements, to provide sourish taste, to prevent color and flavor losses and tarnishing (Dauthy, 1995). Oxalic acid is a free acid and generally encountered as calcium salt (Çalışkan, 2000). Oxalate quantities greatly vary based on plant family and organs, growing conditions, climate and growth periods. When high oxalate-containing vegetables (spinach: 1959 $\mathrm{mg} / 100 \mathrm{~g}$ ) were consumed, oxalate forms insoluble complexes with divalent cations and results in formation of calcium oxalate stone. As compared to those vegetables, peppers have quite low oxalic acid contents.

Ascorbic acid is an important organic acid and is required mostly to prevent scurvy. There are earlier studies indicating decreasing (Subramanian et al., 2006) or increasing (Nahar and Gretzmacher, 2002) ascorbic acid contents with different irrigation levels. Role of proline was also mentioned in ascorbate glutathione cycle including ascorbic acid (Islam et al., 2009; Aggarwal et al., 2011).

Besides the studies indicating insignificant differences in phenolic quantities with water stress, there are also some other studies indicating increasing proline contents, soluble solids content and total phenolics with water stress treatments. Researchers also reported significant correlations of antioxidant activity with total phenols and ascorbic acid content of peppers (Estiarte et al. 1994; Mohamed et al. 2014; Ghasemnezhad et al., 2011). 
Peppers are known to be sensitive to water stress and proline has protective effects against certain stressors. Therefore, this study was conducted to investigate the effects of different irrigation levels and proline treatments on yield parameters, soluble solids content, total phenolics, proline content and organic acids of peppers.

\section{Materials and methods}

This study was conducted at the experimental fields of Research and Implementation Center of Çanakkale Onsekiz Mart University Agricultural Faculty in Turkey from 2013 to 2014 (Figure 1). Seedlings of Yalova Yağlık 28 pepper cultivar (Asgen Tarım A.Ş.) (Capsicum annum L. cv. Yalova Yağlik 28) was used as the plant material of the study which is a preferred cultivar by farmers in region especially for it's speciality as an industrial pepper. Yalova yağlık 28 is a mid-season cultivar growing for industy and fresh consumption and avaliable for field or greenhouse cultivation. It has sweet and industrial type fruits which are large and conic. Average fruit weight is $90 \mathrm{~g}$, fruit colour is dark red and fruit flesh thickness is $4.8 \mathrm{~mm}$ and these characters strictly infleunced by irrigation.

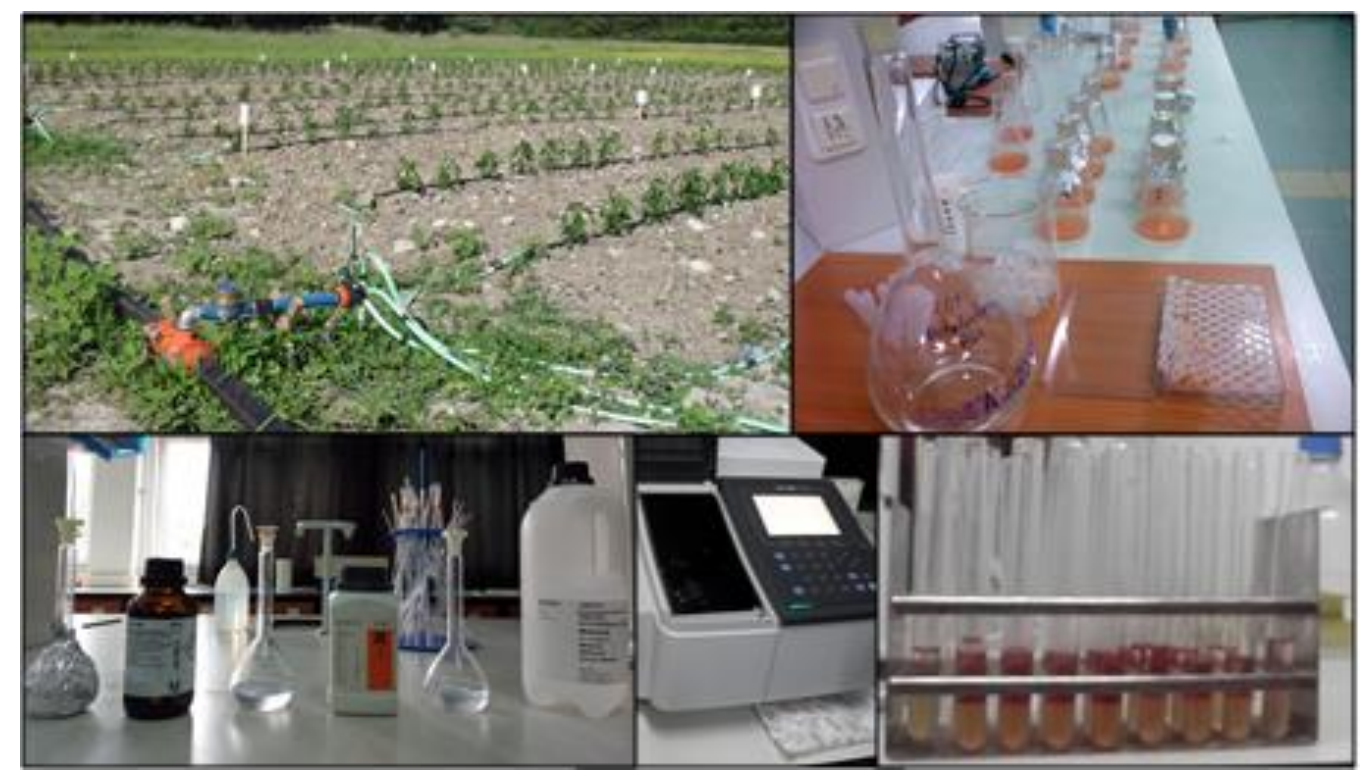

Figure 1. Photos from area of experiment, organic acid, total phenolics and internal proline analyzes

Three different irrigation levels were used in experiments. For different irrigation levels, pan-coefficients (Kcp) were used $\left(\mathrm{Kcp}_{50}, \mathrm{Kcp}_{100}, \mathrm{Kcp}_{150}\right)$. For each pancoefficient, proline treatments $(12 \mathrm{mM})$ were performed at 3 different growth stages.

Cumulative evaporations from Class-A pan placed at experimental site were measured with a depth gauge and irrigations were performed as to have $\mathrm{Kcp}_{50}=50 \%$, $\mathrm{Kcp}_{100}=100 \%$ and $\mathrm{Kcp}_{150}=150 \%$ of cumulative evaporation at a single irrigation interval (3-day) through constant-pressure drip lines (4 lt/h) (Y1ldırım, 1996; Doorenbos and Pruit, 1992). Calculation of irrigation water quantity to be applied is shown at Table 1. 
Table 1. Calculation of irrigation water quantity to be applied

\begin{tabular}{|c|c|c|c|}
\hline $\begin{array}{c}\mathbf{N = 1 0 0 0 / L S} * \mathbf{D S} \\
\text { (Eq. } 1)\end{array}$ & $\mathbf{I}=\mathbf{E p a n} * \mathbf{K c p} * \mathbf{P}(\mathrm{Eq} .2)$ & $\begin{array}{c}\mathbf{T a}=\mathbf{1 0 0 0} * \mathbf{d t} / \mathbf{q} * \mathbf{N} \\
(\mathrm{Eq} .3)\end{array}$ & $\mathbf{E T}=\mathbf{I}+\mathbf{P} \pm \Delta \mathbf{s}($ Eq.4) \\
\hline $\begin{array}{c}\text { N: Number of dripper } \\
\text { (dripper/da) } \\
\text { LS: Lateral spacing } \\
\text { (m) } \\
\text { DS: Dripper spacing } \\
\text { (m) }\end{array}$ & $\begin{array}{l}\text { I: Amount of irrigation } \\
\text { water to be applied } \\
\text { (mm) } \\
\text { Epan: Cumulative } \\
\text { evaporation from Class- } \\
\text { A pan (mm) } \\
\text { Kcp: Plant-Pan } \\
\text { Coefficient } \\
\text { P: Plant cover } \\
\text { percentage }(\%)\end{array}$ & $\begin{array}{l}\text { Ta: Irrigation duration } \\
\text { (hours) } \\
\text { dt: Amount of irrigation } \\
\text { water to be applied (I) } \\
\text { (mm) } \\
\text { q: Dripper discharge (4 } \\
\text { lt/h) } \\
\text { N: Number of drippers } \\
\text { (dripper/da) }\end{array}$ & $\begin{array}{c}\text { ET: Plant water } \\
\text { consumption } \\
\text { I: Amount of } \\
\text { irrigation water to be } \\
\text { applied (mm) } \\
\text { P: Precipitation }(\mathrm{mm}) \\
\Delta \mathrm{s} \text { : Change in soil } \\
\text { moisture (mm) }\end{array}$ \\
\hline
\end{tabular}

Seedlings were divided into three groups as to cover each pan-coefficient. The first group was subjected to proline treatments three times at 10-day intervals with the first treatment applied $20^{\text {th }}$ day of seedling plantation. The second group was subjected to single proline treatment on $30^{\text {th }}$ day of seedling plantation. The third group had also a single proline treatment on $40^{\text {th }}$ day of seedling plantation.

Proline (Merck KGaA 64271 Darmstadt Germany) treatments were applied at the dose of $12 \mathrm{mM}$ through foliar sprays. In the first group, total dose was separated into 3 equal doses and applied at 3 different periods. In the second and third groups, total dose was applied in a single treatment (Silva Sa et al., 2016). Experiments were conducted in randomized blocks split plots experimental design with 3 replications. Each treatment had 5 plant rows with 7 plants in each row (35 plants for each treatment). Experiments were then composed of $1260(35 * 12 * 3)$ plants and $36(12 * 3)$ plots. Analyses and measurements were performed on 10 plants randomly selected from 15 plants left after removing 20 plants as to consider side effects. Experimental design was separated into 3 blocks and the first replication of each treatment was placed in every block.

Soil samples were taken from $0-30 \mathrm{~cm}$ soil profile and a fertilization program was applied based on soil analysis results (Table 2).

Table 2. Soil analysis results

\begin{tabular}{c|c|c|cc}
\hline & \multicolumn{2}{|c|}{$\mathbf{2 0 1 3}$} & \multicolumn{2}{c}{$\mathbf{2 0 1 4}$} \\
\hline Analysis & Results & Assessment & Results & Assessment \\
\hline Saturation (\%) & 50 & Clay-Loam & 70 & Clay-Loam \\
pH & 7,79 & Slightly alkaline & 7,76 & Slightly alkaline \\
Lime (\%) & 11,06 & Limy & 14,88 & Limy \\
Organic Matter (\%) & 2,071 & Moderate & 2,03 & Moderate \\
Salt (\%) & 0,044 & Unsaline & 0,93 & Unsaline \\
Phosphorus (P) kg/da- & $12,18-48,72$ & Moderate & $12,30-49,2$ & Moderate \\
ppm & & High & $64,5-258$ & High \\
Potassium (K) kg/da- & $66,215-264,86$ & & &
\end{tabular}

In the years 2013-2014, Ammonium Nitrate (33\% N), Mono Ammonium Phosphate $(12 \% \mathrm{~N}+61 \% \mathrm{P} 2 \mathrm{O} 5)$ and Potassium Nitrate $\left(\mathrm{KNO}_{3}\right)(13 \% \mathrm{~N}, 13 \% \mathrm{~N}-\mathrm{NO} 3,45,5 \%$ $\mathrm{K} 2 \mathrm{O}$ ) fertilizers were applied through drip irrigation (fertigation). Meteorological data for experimental years is shown in Table 3. 


\section{Experimental Treatments}

- Kcp ${ }_{50}$ : Without proline treatment

- $\mathrm{Kcp}_{50}: 4 \mathrm{mM}\left(20^{\text {th }}\right.$ day $)+4 \mathrm{mM}\left(30^{\text {th }}\right.$ day $)+4 \mathrm{mM}\left(40^{\text {th }}\right.$ day $)$

- Kcp50: $12 \mathrm{mM}\left(30^{\text {th }}\right.$ day $)$

- Kcp50: 12 mM (40 ${ }^{\text {th }}$ day)

- Kcp - $_{100}$ : Without proline treatment

- Kcp $100: 4 \mathrm{mM}\left(20^{\text {th }}\right.$ day $)+4 \mathrm{Mm}\left(30^{\text {th }}\right.$ day $)+4 \mathrm{mM}\left(40^{\text {th }}\right.$ day $)$

- Kcp $100: 12 \mathrm{mM}\left(30^{\text {th }}\right.$ day $)$

- Kcp $100: 12 \mathrm{mM}\left(40^{\text {th }}\right.$ day $)$

- Kcp ${ }_{150}$ : Without proline treatment

- $\mathrm{Kcp}_{150}: 4 \mathrm{mM}\left(20^{\text {th }}\right.$ day $)+4 \mathrm{mM}\left(30^{\text {th }}\right.$ day $)+4 \mathrm{mM}\left(40^{\text {th }}\right.$ day $)$

- Kcp $150: 12 \mathrm{mM}\left(30^{\text {th }}\right.$ day $)$

- Kcp $150: 12 \mathrm{mM}\left(40^{\text {th }}\right.$ day $)$

Table 3. Meteorological data for experimental years

\begin{tabular}{|c|c|c|c|c|c|c|}
\hline \multicolumn{7}{|c|}{ Monthly Average Temperature $\left({ }^{\circ} \mathrm{C}\right)$} \\
\hline Year/Month & January & February & March & April & May & June \\
\hline 2013 & 7,9 & 8,8 & 10,4 & 14,0 & 19,8 & 23,0 \\
\hline 2014 & 9,3 & 9,1 & 10,6 & 13,9 & 18,1 & 22,1 \\
\hline Year/Month & July & August & September & October & November & December \\
\hline 2013 & 25,7 & 26,7 & 21,6 & 14,8 & 13,5 & 6.6 \\
\hline 2014 & 25,5 & 26,1 & 21,4 & 16,1 & 11,8 & 10,2 \\
\hline \multicolumn{7}{|c|}{ Monthly Average Sunshine Duration (hours) } \\
\hline Year/Month & January & February & March & April & May & June \\
\hline 2013 & 95,3 & 94,8 & 172,4 & 237,5 & 303,9 & 322,8 \\
\hline 2014 & 73,0 & 122,9 & 160,4 & 174,1 & 240,9 & 273,2 \\
\hline Year/Month & July & August & September & October & November & December \\
\hline 2013 & 376,3 & 356,6 & 292,2 & 245,4 & 123,3 & 79,3 \\
\hline 2014 & 244,7 & 234,8 & 238,2 & 155,5 & 96,0 & 69,4 \\
\hline \multicolumn{7}{|c|}{ Monthly Average Wind Speed $\left(\mathrm{m} \mathrm{s}^{-1}\right)$} \\
\hline Year/Month & January & February & March & April & May & June \\
\hline 2013 & 4,3 & 3,9 & 2,2 & 3,1 & 3,9 & 3,2 \\
\hline 2014 & 3,7 & 3,6 & 3,5 & 3,4 & 3,6 & 2,8 \\
\hline Year/Month & July & August & September & October & November & December \\
\hline 2013 & 4,0 & 4,2 & 2,8 & 3,2 & 3,6 & 3,5 \\
\hline 2014 & 3,2 & 3,4 & 3,0 & 4,0 & 2,9 & 3,4 \\
\hline \multicolumn{7}{|c|}{ Monthly Average Precipitation $\left(\mathrm{mm}=\mathrm{kg} \mathrm{m}^{-2}\right)$ MANUEL } \\
\hline Year/Month & January & February & March & April & May & June \\
\hline 2013 & 167,4 & 141,6 & 59,0 & 90,3 & 5,6 & 21,7 \\
\hline 2014 & 54,2 & 1,0 & 80,4 & 101,4 & 27,0 & 75,4 \\
\hline Year/Month & July & August & September & October & November & December \\
\hline 2013 & 0,2 & - & 10,2 & 92,7 & 50,8 & 10,7 \\
\hline 2014 & 33,3 & 8,0 & 66,6 & 44,4 & 109,2 & 154,4 \\
\hline
\end{tabular}

\section{Investigated parameters}

Yield $\left(\mathrm{g} \mathrm{m}^{-2}\right)$

Fruit weights were measured with a precise balance $( \pm 0.01)$ (GM2202, Sartorius, Göttingen, Germany) and total yield of each treatment was determined. 


\section{Total Soluble Solids Content (\%)}

Atago PAL 1 model digital hand refractometer (Pal-1, Atago, Tokyo, Japan) was used to determine soluble solids content $(\%)$.

\section{Total Phenolics ( $\mathrm{mg} / \mathrm{lo0g})$}

Total phenolics of the samples were determined from $5 \mathrm{~g}$ fruit puree in accordance with Folin-Ciocalteu method at $765 \mathrm{~nm}$ absorbance value of a Shimadzu UV-VIS spectrophotometer (UV-Vis Spectrophotometer, Shimadzu Corporation, Tokyo-Japan) $(\mathrm{mg} / 100 \mathrm{~g})$. For each sample, $5 \mathrm{~g}$ fruit juice was supplemented with $5 \mathrm{ml}$ Methanol. The mixture was centrifuged at $4000 \mathrm{rpm}$ for 10 minutes. Samples were then supplemented with 2,5 $\mathrm{ml} 10 \%$ Folin-Ciocalteu and $2 \mathrm{ml} 1 \mathrm{M} \mathrm{Na}_{2} \mathrm{CO}_{3}$ and this mixture was kept in hot-water bath at $45^{\circ} \mathrm{C}$ for 15 minutes. Samples were removed from the hot-water bath and readings were performed at $765 \mathrm{~nm}$ absorbance value of a spectrophotometer against $10 \%$ Folin-Ciocalteu and results were expressed in total gallic acid equivalent (GAE) $\mathrm{mg} / 100 \mathrm{~g}$ (Zheng and Wang, 2001).

\section{Internal Proline Content ( $\mu \mathrm{mol} / \mathrm{g}$ )}

For proline contents, $0.5 \mathrm{~g}$ fresh leaf samples were finely chopped and homogenized in $10 \mathrm{ml} \mathrm{3 \%} \mathrm{5-Sulphuric} \mathrm{acid} \mathrm{for} 2$ minutes. Resultant homogenate was filtered through Whatman No. 2 filter paper and placed into tubes. About $2 \mathrm{ml}$ of filtrate was supplemented with $2 \mathrm{ml}$ ninhydrine and $2 \mathrm{ml}$ glacial acid in a test tube and put into reaction in a water bath at $100{ }^{\circ} \mathrm{C}$ for 1 hour. Then the test tubes were taken into icebath and reaction was terminated. Samples were then supplemented with $4 \mathrm{ml}$ toluene and reaction mixture was mixed in a tube-mixer for 15-20 seconds. The chromophore phase was aspired with a thin-probe pipette into spectrophotometer tubes. When reached to room temperature, chromophore-containing toluene tubes were then subjected to absorbance readings in Shimadzu UV-VIS spectrophotometer (UV-Vis Spectrophotometer, Shimadzu Corporation, Tokyo-Japan) at $520 \mathrm{~nm}$. Toluene was used as the control (Bates et al., 1973).

\section{HPLC analysis for organic acids ( $m g / 100 g)$}

The simultaneous determination of oxalic, tartaric, malic, lactic, acetic, citric, succinic acids and ascorbic acids using liquid chromatography was carried out according to (Arnetoli et al., 2008). The chromatography analysis was carried out using a HPLC system (Shimadzu, Japan). The equipments of HPLC system consist of LC20AD SP pump, SIL- 10AP Auto sampler, SCL-10A vp system controller, SPD-20A Prominence UV detector, CTO-20AC sp column oven and LC solution (version: 1.23 sp1) software. An Inertsil ODS-III C18 column (46x150 ID, $5 \mu \mathrm{m}$ particle size) was used for the chromatographic separation. The mobile phase was carried out with 125 $\mathrm{mM}$ KH2PO4 adjusted to $\mathrm{pH} 2.5$ with o-phosphoric acid. The flow rate of mobile phase was performed as $1 \mathrm{ml} / \mathrm{min}$. The wavelengths of the UV detection were performed at $210 \mathrm{~nm}$ for oxalic, tartaric, malic, lactic, acetic, citric, succinic acids, and $254 \mathrm{~nm}$ for ascorbic acid. 


\section{Statistical analysis}

Experimental data were subjected to variance analysis with SAS.9.1.3 software. Significant means were compared with LSD test. Biplot analysis was used for interpretation of organic acids data.

\section{Results}

Yield $\left(\mathrm{g} \mathrm{m}^{-2}\right)$

Table 4. Effects of different irrigation levels and proline treatments on fruit yields $\left(\mathrm{g} \mathrm{m}^{-2}\right)$ $(P-=$ Treatments without proline, $P 1=$ Proline treatments on 20,30 and 40 th days, $P 2=$ Proline treatments on 30th day, $P 3=$ Proline treatments on 40th day)

\begin{tabular}{|c|c|c|c|c|c|}
\hline \multicolumn{6}{|c|}{ Yield $\left(\mathrm{g} \mathrm{m}^{-2}\right)$} \\
\hline \multicolumn{6}{|c|}{$1^{\text {st }}$ year } \\
\hline Treatments & P- $(1,5,9)$ & P1 $(2,6,10)$ & P2 $(3,7,11)$ & P3 $(4,8,12)$ & Kcp mean \\
\hline Kcp1=0.5 & $1003 \mathrm{~d}$ & $1110 \mathrm{c}$ & $1113 \mathrm{c}$ & $1121 \mathrm{c}$ & $1087 \mathrm{C}$ \\
\hline Kcp2=1 & $1676 \mathrm{~b}$ & $1680 \mathrm{~b}$ & $1684 \mathrm{~b}$ & $1692 \mathrm{~b}$ & $1683 \mathrm{~B}$ \\
\hline Kcp3 $=1.5$ & $1862 \mathrm{a}$ & $1866 \mathrm{a}$ & $1868 \mathrm{a}$ & $1875 \mathrm{a}$ & $1868 \mathrm{~A}$ \\
\hline $\mathrm{P}$ mean & $1514 \mathrm{~B}$ & $1552 \mathrm{~A}$ & $1555 \mathrm{~A}$ & $1563 \mathrm{~A}$ & \\
\hline \multicolumn{6}{|c|}{$2^{\text {nd }}$ year } \\
\hline Kcp1=0.5 & $1083 \mathrm{~d}$ & $1199 \mathrm{c}$ & $1210 \mathrm{c}$ & $1213 \mathrm{c}$ & $1176 \mathrm{C}$ \\
\hline Kcp2=1 & $1809 \mathrm{~b}$ & $1818 \mathrm{~b}$ & $1826 \mathrm{~b}$ & $1821 \mathrm{~b}$ & $1818 \mathrm{~B}$ \\
\hline Kcp3=1.5 & $2044 \mathrm{a}$ & $2055 \mathrm{a}$ & $2047 \mathrm{a}$ & $2059 \mathrm{a}$ & $2051 \mathrm{~A}$ \\
\hline $\mathrm{P}$ mean & $1645 \mathrm{~B}$ & $1691 \mathrm{~A}$ & $1694 \mathrm{~A}$ & $1697 \mathrm{~A}$ & \\
\hline \multicolumn{6}{|c|}{ MEAN } \\
\hline $\mathrm{Kcp} 1=0.5$ & $1043 d$ & $1154 \mathrm{c}$ & $1162 \mathrm{c}$ & $1167 \mathrm{c}$ & $1131 \mathrm{C}$ \\
\hline Kcp2=1 & $1742 \mathrm{~b}$ & $1750 \mathrm{~b}$ & $1755 \mathrm{~b}$ & $1756 \mathrm{~b}$ & $1751 \mathrm{~B}$ \\
\hline Kcp3 $=1.5$ & $1953 \mathrm{a}$ & $1961 \mathrm{a}$ & 1957 a & $1967 \mathrm{a}$ & $1959 \mathrm{~A}$ \\
\hline $\mathrm{P}$ mean & $1579 \mathrm{~B}$ & $1621 \mathrm{~A}$ & $1625 \mathrm{~A}$ & $1630 \mathrm{~A}$ & \\
\hline \multicolumn{6}{|c|}{ Yield in $2013(\mathrm{~g} / \mathrm{m} 2): \mathrm{P} \times \mathrm{Kcp}<0.01 \mathrm{LSD}=66.624 ; \mathrm{Kcp}<0.01 \mathrm{LSD}=82.179 ; \mathrm{P}<0.01 \mathrm{LSD}=33.221$} \\
\hline \multicolumn{6}{|c|}{ Yield in $2014(\mathrm{~g} / \mathrm{m} 2)$ : $\mathrm{P} \times \mathrm{Kcp}<0.01 \mathrm{LSD}=50.553 ; \mathrm{Kcp}<0.01 \mathrm{LSD}=33.049 ; \mathrm{P}<0.01 \mathrm{LSD}=30.972$} \\
\hline \multicolumn{6}{|c|}{ Mean yield $(\mathrm{g} / \mathrm{m} 2): \mathrm{P} \times \mathrm{Kcp}<0.01 \mathrm{LSD}=44.649 ; \mathrm{Kcp}<0.01 \mathrm{LSD}=49.883 ; \mathrm{P}<0.01 \mathrm{LSD}=23.638$} \\
\hline
\end{tabular}

In the first year of the experiments, fruit yield per plant of irrigation treatments were gathered under three groups. Yields increased with increasing irrigation levels (Table 4). With regard to effects of proline treatments on fruit yields, treatments were gathered under two groups. Proline treatments yielded similar values, but greater values than the control treatments. With regard to effects of interactions (irrigation x proline) on fruit yields, interactions were gathered under 4 groups. In treatments without proline $(1,5$, $9)$, increasing fruit yields were observed with increasing irrigation levels $(\mathrm{Kcp} 50=397,48, \mathrm{Kcp} 100=663,67, \mathrm{Kcp} 150=737,58)$.

In treatments without proline, similar yield values were observed at the same irrigation levels.

Similar statistical groups were observed in the second year of the experiments and for the mean values of years. 


\section{Soluble Solids Content, SSC (\%)}

In the first year of the experiments, soluble solids content (SSC) of irrigation treatments were gathered under three groups and increasing SSC values were observed with decreasing irrigation levels (Table 5). The differences in SSC values of the proline treatments were not found to be significant. With regard to effects of irrigation $\mathrm{x}$ proline interactions on SSC values, interactions were gathered under three groups and increasing SSC values were observed with decreasing irrigation levels (Kcp $50=9,4 \%$, $\left.\mathrm{Kcp}_{100}=8,1 \%, \mathrm{Kcp}_{150}=7,8 \%\right)$.

The differences in SSC values of the treatments with and without proline were not found to be significant at the same irrigation level.

Similar statistical groups were observed in the second year of the experiments and for the mean values of years

Table 5. Effects of different irrigation levels and proline treatments on soluble solids content (\%) $(P-=$ Treatments without proline, $P 1=$ Proline treatments on 20, 30 and 40 th days, $P 2=$ Proline treatments on 30th day, $P 3=$ Proline treatments on 40th day, N.S.: Not-significant)

\begin{tabular}{|c|c|c|c|c|c|}
\hline \multicolumn{6}{|c|}{ Soluble Solids Content, SSC (\%) } \\
\hline \multicolumn{6}{|c|}{$1^{\text {st }}$ year } \\
\hline Treatments & P- $(1,5,9)$ & P1 $(2,6,10)$ & P2 $(3,7,11)$ & P3 $(4,8,12)$ & Kcp mean \\
\hline Kcp1=0.5 & $9.4 \mathrm{a}$ & $9.5 \mathrm{a}$ & $9.4 \mathrm{a}$ & $9.4 \mathrm{a}$ & $9.4 \mathrm{~A}$ \\
\hline $\mathrm{Kcp} 2=1$ & $8.1 \mathrm{~b}$ & $8.2 \mathrm{~b}$ & $8.2 \mathrm{~b}$ & $8.2 \mathrm{~b}$ & $8.1 \mathrm{~B}$ \\
\hline $\mathrm{Kcp} 3=1.5$ & $7.8 \mathrm{c}$ & $7.8 \mathrm{c}$ & $7.8 \mathrm{c}$ & $7.8 \mathrm{c}$ & $7.8 \mathrm{C}$ \\
\hline P mean & 8.4 & 8.5 & 8.4 & 8.5 & \\
\hline \multicolumn{6}{|c|}{$2^{\text {nd }}$ year } \\
\hline Kcp1=0.5 & $8.4 \mathrm{a}$ & $8.5 \mathrm{a}$ & $8.5 \mathrm{a}$ & $8.5 \mathrm{a}$ & $8.5 \mathrm{~A}$ \\
\hline Kcp2=1 & $7.6 \mathrm{~b}$ & $7.6 \mathrm{~b}$ & $7.6 \mathrm{~b}$ & $7.6 \mathrm{~b}$ & $7.6 \mathrm{~B}$ \\
\hline $\mathrm{Kcp} 3=1.5$ & $7.3 \mathrm{c}$ & $7.3 \mathrm{c}$ & $7.3 \mathrm{c}$ & $7.3 \mathrm{c}$ & $7.3 \mathrm{C}$ \\
\hline $\mathrm{P}$ mean & 7.8 & 7.8 & 7.8 & 7.8 & \\
\hline \multicolumn{6}{|c|}{ MEAN } \\
\hline Kcp1 $1=0.5$ & $8.9 \mathrm{a}$ & $9 \mathrm{a}$ & $9 a$ & $9 a$ & $9 \mathrm{~A}$ \\
\hline $\mathrm{Kcp} 2=1$ & $7.9 \mathrm{~b}$ & $7.9 \mathrm{~b}$ & $7.9 \mathrm{~b}$ & $7.9 \mathrm{~b}$ & $7.9 \mathrm{~B}$ \\
\hline $\mathrm{Kcp} 3=1.5$ & $7.6 \mathrm{c}$ & $7.5 \mathrm{c}$ & $7.6 \mathrm{c}$ & $7.6 \mathrm{c}$ & $7.6 \mathrm{C}$ \\
\hline P mean & 8.1 & 8.2 & 8.1 & 8.2 & \\
\hline \multicolumn{6}{|c|}{$\mathrm{SSC}$ in $2013(\%): \mathrm{P} \times \mathrm{Kcp}<0.01 \mathrm{LSD}=0.284 ; \mathrm{Kcp}<0.01 \mathrm{LSD}=0.263 ; \mathrm{P}<0.05 \mathrm{LSD}=\mathrm{N} . \mathrm{S}}$. \\
\hline \multicolumn{6}{|c|}{$\mathrm{SSC}$ in $2014(\%): \mathrm{P} \times \mathrm{Kcp}<0.01 \mathrm{LSD}=0.2136 ; \mathrm{Kcp}<0.01 \mathrm{LSD}=0.1366 ; \mathrm{P}<0.05 \mathrm{LSD}=\mathrm{N} . \mathrm{S}$} \\
\hline \multicolumn{6}{|c|}{ Mean SSC (\%): $\mathrm{P} \times \mathrm{Kcp}<0.01 \mathrm{LSD}=0.1777 ; \mathrm{Kcp}<0.01 \mathrm{LSD}=0.1981 ; \mathrm{P}<0.05 \mathrm{LSD}=\mathrm{N} . \mathrm{S}}$. \\
\hline
\end{tabular}

\section{Total Phenolics (GAE mg/100g)}

In the first year of the experiments, total phenolics of irrigation treatments were gathered under three different groups and decreasing total phenolics were observed with increasing irrigation levels (Table 6). Considering the mean values of proline treatments, it was observed that treatments were gathered under two different groups and proline-treated group had greater total phenolics than the untreated group.

With regard to effects of irrigation $\mathrm{x}$ proline interactions on total phenolics, interactions were gathered under three different groups and increasing total phenolics were observed with decreasing irrigation levels in treatments without proline $\left(\mathrm{Kcp}_{150}=1317,9, \mathrm{Kcp}_{100}=1383,1, \mathrm{Kcp}_{50}=1447,3 \mathrm{mg} \mathrm{GAE} / 100 \mathrm{~g}\right)$. In Kcp $\mathrm{K}_{50}$ irrigation 
treatments, total phenolics had similar values in proline-treated groups $(2,3,4)$ and such values were greater than non-proline-treated group (1). In Kcp 100 irrigation treatments, proline-treated and untreated groups $(5,6,7,8)$ had similar total phenolics. In Kcp 150 irrigation treatments, a similar case was observed in proline-treated and untreated groups $(9,10,11,12)$. Similar statistical groups were observed in 2014 and for the mean values of the years.

Table 6. Effects of different irrigation levels and proline treatments on total phenolics (GAE $m g / 100 g)(P-=$ Treatments without proline, $P 1=$ Proline treatments on 20, 30 and 40 th days, $P 2=$ Proline treatments on 30th day, $P 3=$ Proline treatments on 40th day.)

\begin{tabular}{|c|c|c|c|c|c|}
\hline \multicolumn{6}{|c|}{ Total Phenolics (GAE mg/100g) } \\
\hline \multicolumn{6}{|c|}{$1^{\text {st }}$ year } \\
\hline Treatments & P- $(1,5,9)$ & P1 $(2,6,10)$ & P2 $(3,7,11)$ & P3 $(4,8,12)$ & Kcp mean \\
\hline Kcp1 $=0.5$ & $1447.3 \mathrm{~b}$ & $1497 \mathrm{a}$ & $1505.7 \mathrm{a}$ & $1502.9 \mathrm{a}$ & $1488.2 \mathrm{~A}$ \\
\hline Kср2=1 & $1383.1 \mathrm{c}$ & $1393.3 \mathrm{c}$ & $1391.6 \mathrm{c}$ & $1392.4 \mathrm{c}$ & $1390.1 \mathrm{~B}$ \\
\hline $\mathrm{Kcp} 3=1.5$ & $1317.9 \mathrm{~d}$ & $1319.8 \mathrm{~d}$ & $1320.8 \mathrm{~d}$ & $1316.8 \mathrm{~d}$ & $1318.8 \mathrm{C}$ \\
\hline P mean & $1382.7 \mathrm{~B}$ & $1403.4 \mathrm{~A}$ & $1406 \mathrm{~A}$ & $1404 \mathrm{~A}$ & \\
\hline \multicolumn{6}{|c|}{$2^{\text {nd }}$ year } \\
\hline Kcp1 $=0.5$ & $1418.3 \mathrm{~b}$ & $1482.4 \mathrm{a}$ & $1479.7 \mathrm{a}$ & $1478.4 \mathrm{a}$ & $1464.7 \mathrm{~A}$ \\
\hline $\mathrm{Kcp} 2=1$ & $1346.7 \mathrm{c}$ & $1349.8 \mathrm{c}$ & $1352.5 \mathrm{c}$ & $1347.5 \mathrm{c}$ & $1349.1 \mathrm{~B}$ \\
\hline $\mathrm{Kcp} 3=1.5$ & $1292.4 \mathrm{~d}$ & $1294.1 \mathrm{~d}$ & $1297 \mathrm{~d}$ & $1295.3 \mathrm{~d}$ & $1294.7 \mathrm{C}$ \\
\hline$P$ mean & $1352.4 \mathrm{~B}$ & $1375.5 \mathrm{~A}$ & $1376.4 \mathrm{~A}$ & $1373.7 \mathrm{~A}$ & \\
\hline \multicolumn{6}{|c|}{ MEAN } \\
\hline Kcp1=0.5 & $1432.8 \mathrm{~b}$ & $1489.7 \mathrm{a}$ & $1492.7 \mathrm{a}$ & $1490.7 \mathrm{a}$ & $1476.5 \mathrm{~A}$ \\
\hline $\mathrm{Kcp} 2=1$ & $1364.9 \mathrm{c}$ & $1371.6 \mathrm{c}$ & $1372.1 \mathrm{c}$ & $1369.9 \mathrm{c}$ & 1369.6 B \\
\hline $\mathrm{Kcp} 3=1.5$ & $1305.2 \mathrm{~d}$ & $1307 \mathrm{~d}$ & $1308.9 \mathrm{~d}$ & $1306 \mathrm{~d}$ & $1306.8 \mathrm{C}$ \\
\hline P mean & $1367.6 \mathrm{~B}$ & $1389.4 \mathrm{~A}$ & $1391.2 \mathrm{~A}$ & 1388.9 A & \\
\hline \multicolumn{6}{|c|}{$\begin{array}{c}\text { Total phenolics in } 2013(\mathrm{mg} / 100 \mathrm{~g}): \mathrm{P} \times \mathrm{Kcp}<0.01 \mathrm{LSD}=46.11 ; \mathrm{Kcp}<0.01 \mathrm{LSD}=65.229 ; \mathrm{P}<0.01 \\
\mathrm{LSD}=20.261\end{array}$} \\
\hline \multicolumn{6}{|c|}{$\begin{array}{c}\text { Total phenolics in } 2014(\mathrm{mg} / 100 \mathrm{~g}): \mathrm{P} \times \mathrm{Kcp}<0.01 \mathrm{LSD}=41.068 ; \mathrm{Kcp}<0.01 \mathrm{LSD}=36.805 ; \mathrm{P}<0.05 \\
\mathrm{LSD}=17.267\end{array}$} \\
\hline \multicolumn{6}{|c|}{$\begin{array}{c}\text { Mean total phenolics (mg/100g): } \mathrm{P} \times \mathrm{Kcp}<0.01 \mathrm{LSD}=31.799 ; \mathrm{Kcp}<0.01 \mathrm{LSD}=44.478 ; \mathrm{P}<0.01 \\
\mathrm{LSD}=14.159\end{array}$} \\
\hline
\end{tabular}

\section{Internal Proline Content ( $\mu \mathrm{mol} / \mathrm{g}$ )}

In both years and for the average of years, effects of irrigation treatments on internal proline contents were gathered under 3 different groups and increasing internal proline contents were observed with decreasing irrigation levels (Table 7). With regard to effects of proline treatments on internal proline contents in the first year of the experiments, treatments were gathered under 4 different groups and proline-treated groups had greater internal proline contents than the untreated groups. In the second year of the experiments, proline treatments gathered under 3 different groups and again proline-treated groups had greater internal proline contents than the untreated groups. In the years 2013 and 2014 and in average of years, the lowest internal proline content in proline treatments was obtained from the treatment with proline treatments on $40^{\text {th }}$ day. 


\section{Organic Acid Compositions}

Effects of different irrigation levels and proline treatments on organic acid composition were assessed through Biplot analysis. Two principle components (PC1 $1^{\text {st }}$ principle component; PC2 $-2^{\text {nd }}$ principle component) were used to generate biplot graph (Figure 2). Organic acid composition values under different irrigation levels and proline treatments in the first year of the experiments $(\mathrm{mg} / 100 \mathrm{~g})$ is also shown in Table 8 .

In the first year of the experiments, $\mathrm{PC} 1$ and PC2 scores for 3 organic acids were able to explain $92 \%$ of 3 irrigation levels and proline treatment interactions (Table 8).

In biplot graph, over the citric acid axis, the Kcp50 irrigation level without proline treatment (1) was the furthest treatment to ascorbic acid axis and such a case indicated that this treatment had quite low ascorbic acid content and high citric acid content. Increasing citric acid contents were reported with drought stress (Sağlam et al., 2010).

Table 8. Organic acid compositions under different irrigation levels and proline treatments in the first year of the experiments $(\mathrm{mg} / \mathrm{l} 00 \mathrm{~g})$

\begin{tabular}{c|c|c|c}
\hline Treatments & Ascorbic Acid & Oxalic Acid & Citric Acid \\
\hline 1 & 84.54 & 34.62 & 486.42 \\
2 & 171.84 & 26.30 & 311.90 \\
3 & 192.99 & 27.77 & 441.20 \\
4 & 130.43 & 56.32 & 260.15 \\
5 & 175.48 & 37.83 & 226.11 \\
6 & 142.45 & 28.19 & 477.73 \\
7 & 183.92 & 19.33 & 380.05 \\
8 & 191.11 & 15.21 & 315.10 \\
9 & 198.92 & 20.77 & 212.79 \\
10 & 161.55 & 18.84 & 274.32 \\
11 & 185.83 & 23.27 & 268.62 \\
12 & 195.19 & 24.42 & 285.22 \\
\hline
\end{tabular}

Considering the treatments without proline $(9,5,1)$, at Kcp50 irrigation level, treatment (1) was placed on positive side of oxalic acid axis $(\mathrm{PC} 1>0, \mathrm{PC} 2>0)$, negative side of ascorbic acid axis $(\mathrm{PC} 1<0)$ and on citric acid axis $(\mathrm{PC} 1>0, \mathrm{PC} 2>0)$, at Kcp100 and Kcp150 irrigation levels, treatments $(5,9)$ were placed on positive side of ascorbic acid axis and negative side of citric acid axis $(\mathrm{PC} 1<0, \mathrm{PC} 2<0)$. Such cases indicated that these treatments $(5,9)$ had greater ascorbic acid and smaller citric and oxalic acid contents than the treatment (1) at Kcp50 irrigation level. As compared to treatment (5) without proline at Kcp100 irrigation level, the treatment (9) without proline at Kcp150 irrigation level was close to ascorbic acid axis and far from citric and oxalic acid axes. Such a case indicated that treatment (9) had greater ascorbic acid and lower oxalic and citric acid contents than the treatment (5).

At Kcp50 irrigation level, $40^{\text {th }}$ day proline treatment (4) was the closest treatment to oxalic acid axis. Such a case indicated that this treatment had the greatest oxalic acid content. 
At Kcp50 irrigation level, the proline treatments on 20,30 and $40^{\text {th }}$ days (2) was placed on graph origin (Figure 1). Such a case indicated that this treatment had quite less variations in all three organic acids than the other treatments. The treatment (1) without proline at Kcp50 irrigation level, treatment (4) with proline treatments on $40^{\text {th }}$ day at Kcp50 irrigation level and treatment (6) with proline treatments on 20, 30 and $40^{\text {th }}$ days at Kcp100 irrigation level were placed further from the ascorbic acid axis as compared to the other treatments. Such a case indicated that these treatments $(1,4,6)$ had lower ascorbic acid contents than the other treatments.

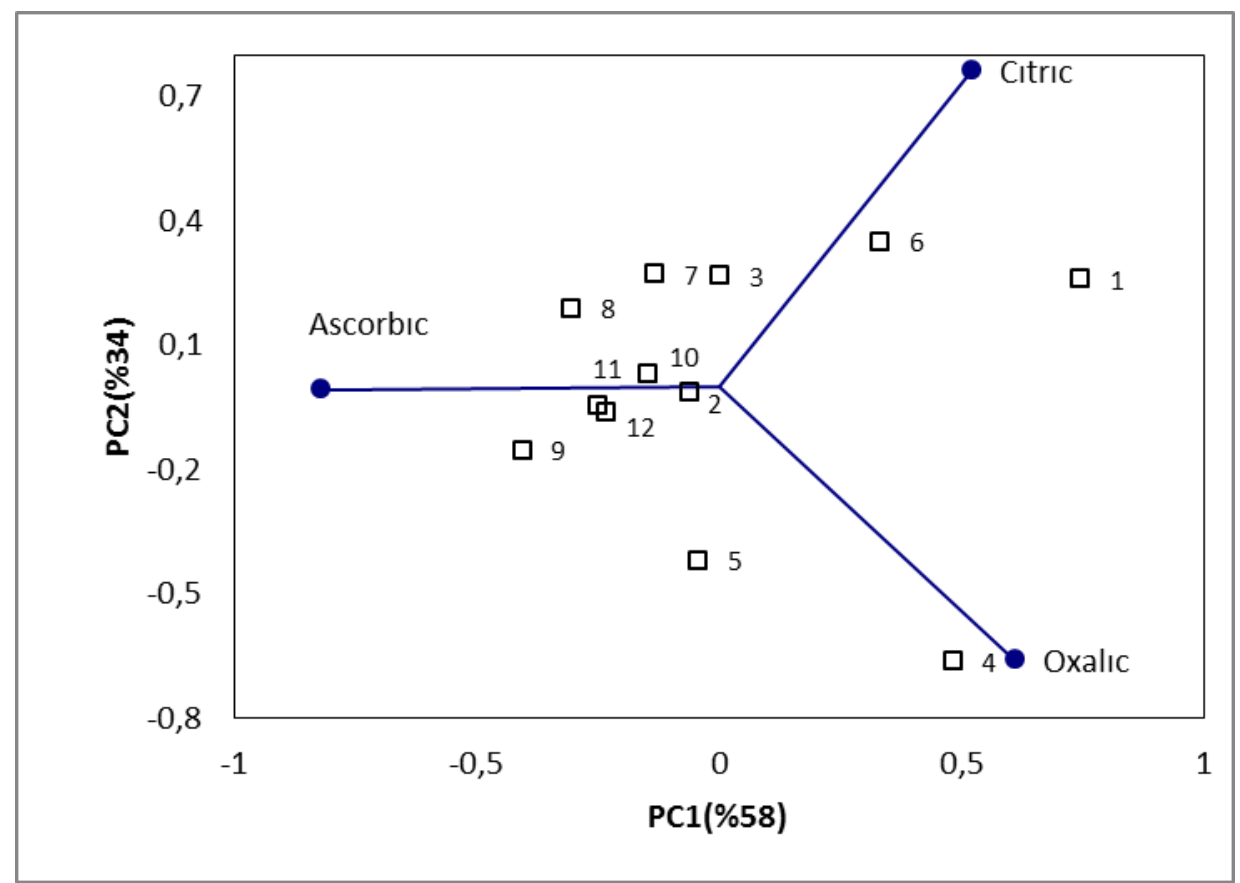

Figure 2. Biplot for the effects of different irrigation levels and proline treatments on organic acid compositions in the first year of the experiments

In the second year of the experiments, PC1 and PC2 scores for 3 organic acids were able to explain $94 \%$ of 3 irrigation levels and proline treatment interactions (Figure 3). Organic acid composition values under different irrigation levels and proline treatments in the second year of the experiments $(\mathrm{mg} / 100 \mathrm{~g})$ is also shown in Table 9.

Considering the treatments without proline $(9,5,1), \mathrm{Kcp}_{50}$ irrigation level (1) was further placed to ascorbic acid axis and closer to citric and oxalic acid axes than the $\mathrm{Kcp}_{100}$ and $\mathrm{Kcp}_{150}$ irrigation levels $(5,9)$ and $\mathrm{Kcp}_{150}$ irrigation level (9) was placed on negative side of citric acid axis $(\mathrm{PC} 1<0, \mathrm{PC} 2<0)$. The closest location of $\mathrm{Kcp}_{150}$ irrigation level with proline treatments on $40^{\text {th }}$ day (12) to ascorbic acid axis indicated that this treatment had the greatest ascorbic acid content. Again, the closest location of $\mathrm{Kcp}_{50}$ irrigation level with proline treatments on $40^{\text {th }}$ day (4) to oxalic acid axis indicated that this treatment had the greatest oxalic acid content.

The $\mathrm{Kcp}_{100}$ with proline on $20^{\text {th }}$ day (6), Kcp 100 with proline on $40^{\text {th }}$ day (8), $\mathrm{Kcp}_{150}$ (9), Kcp $\mathrm{p}_{150}$ with proline on $20^{\text {th }}$ day (10) and $\mathrm{Kcp}_{150}$ with proline on $30^{\text {th }}$ day (11) were placed on the negative side of citric acid axis. Such cases indicated that these treatments had lower citric acid contents. The Kcp50 with proline on $20^{\text {th }}$ day (2), Kcp 50 with proline on $30^{\text {th }}$ day (3) and Kcp 100 with proline on $30^{\text {th }}$ day (7) were placed on positive 
side of citric acid axis and such cases indicated that these treatments had greater citric acid contents.

Table 9. Plant organic acid compositions under different irrigation levels and proline treatments in the second year of the experiments ( $\mathrm{mg} / \mathrm{lo0g}$ )

\begin{tabular}{c|c|c|c}
\hline Treatments & $\begin{array}{c}\text { Ascorbic } \\
\text { Acid }\end{array}$ & Oxalic Acid & Citric Acid \\
\hline 1 & 142.29 & 32.09 & 492.49 \\
2 & 170.60 & 28.37 & 478.87 \\
3 & 245.42 & 26.66 & 512.37 \\
4 & 119.14 & 37.24 & 422.87 \\
5 & 271.47 & 25.53 & 378.87 \\
6 & 236.91 & 24.54 & 325.82 \\
7 & 251.99 & 25.88 & 447.00 \\
8 & 234.87 & 25.81 & 307.53 \\
9 & 248.67 & 26.20 & 301.73 \\
10 & 232.13 & 17.86 & 253.65 \\
11 & 253.66 & 24.21 & 268.41 \\
12 & 273.92 & 15.78 & 316.81 \\
\hline
\end{tabular}

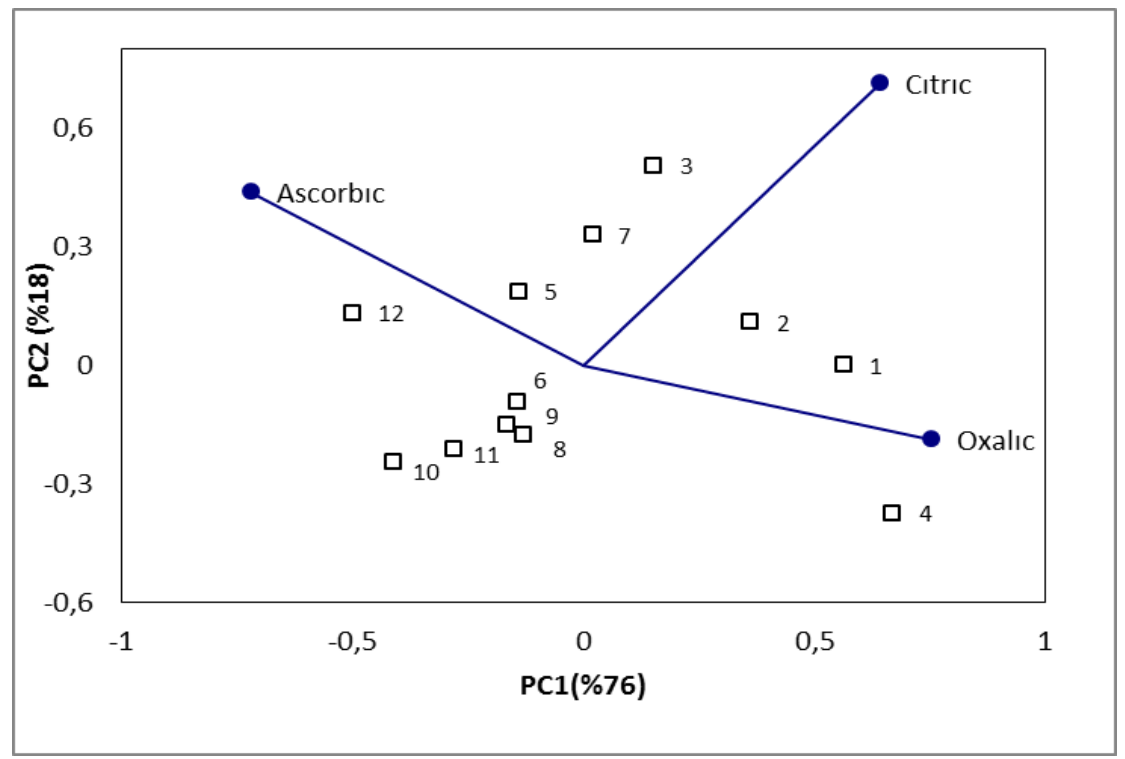

Figure 3. Biplot for the effects of different irrigation levels and proline treatments on organic acid compositions in the second year of the experiments

\section{Discussion}

Present findings revealed that the increase in yield achieved with increasing irrigation levels from Kcp50 to Kcp100 was greater than the increase achieved with increasing irrigation levels from Kcp100 to Kcp150. Decreasing yields were also reported in pepper, tomato and eggplant with water deficits (Kırnak et al., 2016; 
Mitchell et al., 1991; Kirnak et al., 2001). As approached to maximum yield, water use efficiencies decreased and such a case may be related to prevailing climate conditions. Excessive water uses in irrigation is considered as the primary reason of water deficits, thus it was thought that water-yield relations would play significant roles in future water deficits. At Kcp50 irrigation level, an increase was observed in yields with proline treatments, but yields of proline-treated and untreated groups were similar at the other irrigation levels. Such findings indicated that proline treatments were more effective in deficit irrigation conditions.

Farzana (2014) carried out a study with wheat cultivars (BARI Gom-24, BARI Gom26) and reported increasing yields with proline treatments under water deficit, but reported insignificant differences in yields of BARI Gm-24 cultivar with proline treatments under non-water deficit conditions and increasing values in some parameters of BARI Gom-26 cultivar with proline treatments. Increasing yields were reported in tomatoes with proline treatments under salt stress (Öztekin, 2009).

Soluble solids contents (SSC) increased with decreasing irrigation levels, but did not changed significantly with proline treatments. Generally, high SSC values are desired in industrial-type peppers. Either unchanged or increasing SSC values were reported in peppers and tomatoes with drought stress (Shao et al., 2014; Mitchell et al., 1991; Dağdelen et al., 2004). Dorji et al. (2005) applied deficit irrigation and relative root zone dry out treatments to chili pepper (Ancho St. Luis) and reported $21 \%$ increase in SSC values in green and red periods with deficit irrigation. Soluble solids content of tomatoes increased, decreased or remained unchanged with proline treatments under salt stress (Öztekin, 2009). Similar statistical groups were observed in 2014 and for the average of the years. The lowest SSC value (7,3\%) obtained from Yalova Yağlik-28 pepper cultivar was greater than the minimum values specified for red peppers $(6-6,5 \%)$ (Tadesse et al., 2002) and such a case indicated that SSC values of this pepper cultivar will not pose any problems for the producers.

Proline is a non-enzymatic antioxidant (Hossain et al., 2014) and accumulation of proline-like osmatic regulators in cells reduces drought-induced damages in plants (Rontein et al., 2002). Significant correlations were reported between antioxidant capacity and total phenolics of the plants (Li et al., 2008). Anti-radical and antioxidant effects of phenolic acids were also reported (Sroka and Cisowski, 2003) and different free radical-scavenging effects of different phenolics were indicated in previous studies (Aboul-Enein et al., 2007). Nunez Ramirez et al. (2011) investigated the effects of different nitrogen doses $\left(32,80,160,320 \mathrm{~kg} \mathrm{~N}^{-1}\right.$ ) on Habanero chili pepper (Capsicum chinense jacq.) plants and reported increasing TETA values, but unchanged antioxidant activity and total phenols with increasing nitrogen doses. About $86 \%$ increase was reported in total phenolics of sugar beet with water stress (Stagnari et al., 2014).

Internal proline contents increased with decreasing irrigation levels. Such a case indicated a correlation between proline treatments and adaptation to stress conditions. Proline treatments at Kcp50 irrigation level contributed plant adaptation to water stress. Besides proline contents, phenolics playing great roles in prevention of various diseases and contributing fruit color and taste parameters also increased with decreasing irrigation levels.

Ascorbic acid contents increased and oxalic acid contents decreased with increasing irrigation levels. Fluctuations were observed in ascorbic acid contents with proline treatments. In both years of the experiments, the Kcp50 irrigation with proline 
treatments on $20,30,40^{\text {th }}$ days and on $30^{\text {th }}$ day $(2,3)$ had greater ascorbic acid contents than Kcp50 irrigation without proline treatments (1). Such a case indicated positive effects of proline treatments on ascorbic acid contents at this irrigation level. Such an increase in ascorbic acid contents with proline treatments was attributed to increasing enzyme activities in ascorbate glutathione cycle (Islam et al., 2009). Decreasing ascorbate contents were reported in tomatoes with drought stress (Ünyayar et al., 2005) and increasing ascorbic acid contents were reported in wheat (Chakraborty and Pradhan, 2012) and tomatoes (Shao et al., 2014) again with drought stress. In a study carried out with soybean, ascorbic acid contents started to increase from the second day of water deficit and started to decrease after the $8^{\text {th }}$ day of water deficit (Angra et al., 2010).

In another study on tomatoes, ascorbic acid contents were similar in normal and slight drought treatments, but greater in moderate and severe drought treatments (Subramanian et al., 2006). However, it was observed in this study that increasing ascorbic acid contents were also related to water deficit conditions, treatment periods and doses. Such cases indicated in general that citric and oxalic acid contents decreased and ascorbic acid contents increased with increasing irrigation levels. Timpa et al. (1986) indicated that 2-3 times increase in citric acid under drought stress pointed out osmatic regulation. Emam et al. (2014) reported increasing oxalic acid contents in paddy with drought stress treatments. Moreover, decreasing ascorbic acid content (Osuagwu \& Edeoga 2012, Subramanian et al. 2006) and increasing oxalic acid contents (Emam et al. 2014) were reported with water stress.

In treatments without proline, ascorbic acid content at the lowest irrigation level (Kcp50) was lower than the ascorbic acid contents of the other irrigation levels. Such a case indicated that irrigation quantities below certain levels reduced ascorbic acid quantities, which is a significant quality parameter with various positive impacts on human health. Citric acid contents increased in both years with decreasing irrigation levels. Fluctuations were observed in citric acid contents with proline treatments.

\section{Conclusions and recommendations}

In this study, which investigated the effect of proline applications on pepper cultivated with different irrigation levels, the yield was increased with increasing the amount of water. In addition, many quality parameters have also increased. In addition, proline applications had a positive effect on these parameters at the irrigation level with the least amount of water applied, but the effect of proline was found to be decreased at higher irrigation levels. As the irrigation level increased, ascorbic and citric acid values increased and oxalic acid values decreased. It has been determined that proline applications generally have a positive effect on increasing the ascorbic acid value in the subjects where irrigation level is decreased. It can be thought that proline may be effective in improving yield and some other yield and quality parameters, especially in regions with limited irrigation opportunities. High citric acid content is considered as an advantage for the peppers used in canned food industry. Citric acid contents increased with decreasing irrigation levels, thus it was concluded that lower irrigation levels (Kcp50) may be recommended for pepper fruits more available for canned food production. However, more detailed studies on this subject will also help especially the producers producing pepper processed in industry. For this purpose, it will be useful to perform studies in different cultivars. 
Acknowledgements. This study is derived from Tolga Sarıyer's PhD Thesis. Authors wish to thank to Prof. Dr. Mevlut Akçura for performing and interpreting the biplot analyses of organic acids.

\section{REFERENCES}

[1] Aboul-Enein, H. Y., Kruk, I., Kladna, A., Lichszteld, K., Michalska, T. (2007): Scavenging Effects of Phenolic Compounds on Reactive Oxygen Species. - Biopolymers 86(3): 222-230.

[2] Aggarwal, M., Sharma, S., Kaur, N., Pathania, D., Bhandhari, K., Kaushal, N., Kaur, R., Singh, K., Srivastava, A., Nayyar, H. (2011): Exogenous Proline Application Reduces Phytotoxic Effects of Selenium by Minimising Oxidative stress and Improves Growth in Bean (Phaseolus vulgaris L.) Seedlings. - Biol Trace Elem Res (2011) 140: 354-367.

[3] Angra, S., Kaur, S., Singh, K., Pathania, D., Kaur, N., Sharma, S., Nayyar, H. (2010): Water-Deficit Stress During Seed Filling in Contrasting Soybean Genotypes: Association of Stress Sensivity with Profiles of Osmolytes and Antioxidants. - International Journal of Agricultural Research 5(6): 328-345.

[4] Arnetoli, M., Montegrossi, G., Bucciant, A., Gomeli, C. (2008): Determination of organic acids in plants of silene paradoxa L. By Hplc. - J. Agric. Food. Chem. 56: 789-795.

[5] Arnnok, P., Ruangviriyachai, C., Mahachai, R., Techawongstien, S., Chanthai, S., S. (2012): Determination of total phenolics and anthocyanin contents in the pericarp of hot chilli pepper (Capsicum annuиm L.). - International Food Research Journal 19(1): 235243.

[6] Balasundram, N., Sundram, K., Samman, S. (2006): Phenolic compounds in plants and agri-industrial by-products: Antioxidant activity, occurrence, and potential uses. - Food Chemistry 99: 191-203. DOI: 10.1016/j.foodchem.2005.07.042

[7] Bates, L.S., Waldren, R.P., Teare, I.D. (1973): Rapid Determination of Free Proline for Water-Stress Studies. - J. Plant and Soil (39): 205-207.

[8] Bray, E. A. (1997): Plant responses to water deficit. - Trends in Plant Science 2(2): 4854.

[9] Carr, A. C., Frei, B. (1999): Toward a new recommended dietary allowance for vitamin C based on antioxidant and health effects in humans. - The American Journal of Clinical Nutrition 69: 1086-1107.

[10] Çalışkan, M. (2000): The Metabolism of Oxalic Acid. - Turk J Zool. 24: 103-106.

[11] Campos, H., Trejo, C., Pena-Valdivia, C. B., Garcia-Nava, R., Victor Conde-Martinez, F., Cruz-Ortega, M. R. (2014): Stomatal and non-stomatal limitations of bell pepper (Capsicum annuum L.) plants under water stress and re-watering: Delayed restoration of photosynthesis during recovery. - Environmental and Experimental Botany 98: 56-64.

[12] Chakraborty, U., Pradhan, B. (2012): Oxidative stress in five wheat varieties (Triticum aestivum L.) exposed to water stress and study of their antioxidant enzyme defense system, water stress responsive metabolites and $\mathrm{H}_{2} \mathrm{O}_{2}$ accumulation. - Braz. J. Plant Physiol. 24(2): 117-130.

[13] Chanishvili, S., Badridze, H., Rapava, G., Janukashvili. L.,N. (2007): Effect of altitude on the contents of antioxidants in leaves of some herbaceous plants. - Russ. J. col., 38(5): 367-373.

[14] Dağdelen, N., Yilmaz, E., Sezgin, F., Gürbüz, T. (2004): Effects of Water Stress at Different Growth Stages on Processing Pepper (Capsicum annuum cv. Kapija) Yield Water Use and Quality Characteristics. - Pakistan Journal of Biological Sciences 7(12): 2167-2172.

[15] Dauthy, M. E. (1995): Fruit and vegetable processing. - FAO Agricultural Services Bulletin No.119., Italy 128-129.

[16] Doorenbos, J., Pruitt, W. O. (1992): Crop Water Requirements. - Food and Agriculture Org. 144 pp. 
[17] Dorji, K., Behboudian, M. H., Zegbe-Domínguez, J. A. (2005): Water relations, growth, yield, and fruit quality of hot pepper under deficit irrigation and partial rootzone drying. Scientia Horticulturae 104: 137-149.

[18] Emam, M. E., Khattab, H. E., Helal, N. M., Deraz, A. E. (2014): Effect of selenium and silicon on yield quality of rice plant grown under drought stress. - AJCS 8(4): 596-605.

[19] Erken, O. (2012): Değişik gelişme dönemlerinde farklı derecede su stresi uygulamalarının brokkolide (Brassica oleracea L. var. italica) verim, morfolojik ve biyokimyasal değişimlere etkisi (Doktora Tezi) - Çanakkale 18 Mart Üniversitesi, Çanakkale, Türkiye.

[20] Estiarte, M., Filella, I., Serra, J., Penuelas, J. (1994): Effects of nutrient and water stres on leaf phenolic content of peppers and susceptibility to generalist herbivore Helicoverpa armigera (Hubner). - Oecologia 99: 387-391.

[21] Farzana K. (2014): Improving Drought Tolerance In Wheat By Exogenous Application Of Prolıne. Master's Thesis (Yüksek Lisans Tezi). - Bangladesh Agricultural University, Mymensingh, Bangladesh.

[22] Ghasemnezhad, G, Sherafati, M., Payvast, A.G. (2011): variation in phenolic compounds, ascorbic acid and antioxidant activity of five coloured bell pepper (Capsicum annum) fruits at two different harvest times. - J Funct Food 3: 44-49.

[23] Gill, S. S., Tuteja, N. (2010): Reactive oxygen species and antioxidant machinery in abiotic stress tolerance in crop plants. - Plant Physiology and Biochemistry 48: 909-930.

[24] Gutterridge, J. M. C. (1995): Lipid Peroxidation and Antioxidants as Biomarkers of Tissue Damage - Clinical Chemistry 41 (12): 1819-1828. European Beckman Conference.

[25] Howard, L. R., Talcott S. T., Brenes, C. H. B. Villalon. (2000): Changes in Phytochemical and Antioxidant Activity of Selected Pepper Cultivars (Capsicum Species) As Influenced by Maturity. - J. Agric. Food Chem. 48: 1713-1720

[26] Hossain et al. (2014): Proline Protects Plants Against Abiotic Oxidative Stress: Biochemical and Molecular Mechanisms. - ROS Scavenging and Detoxification. Ahmad Parvaiz (Ed.), Oksidative Damage to Plants Antioxidant Networks and Signaling. 485. Elsevier Inc. 525 B Street, Suite 1800, San Diego, CA 92101-4495, USA.

[27] Islam, M. M., Hoque, M. A., Okuma, E., Jannat, R., Banu, M. N. A., Jahan, M. S., Nakamura, Y., Murata, Y. (2009): Proline and Glycinebetaine Confer Cadmium Tolerance on Tobacco Bright Yellow-2 Cells by Increasing Ascorbate-Glutathione Cycle Enzyme Activities. - Bioscience, Biotechnology, and Biochemistry 73(10): 2320-2323.

[28] Kırnak, H., Gökalp, Z., Demir, H., Kodal, S., Yıldırım, E. (2016): Paprika Pepper Yield and Quality as Affected by Different Irrigation Levels. Tarım Bilimleri Dergisi - Journal of Agric ultural Sciences 22: 77-88.

[29] Kirnak, H., Tas, I., Kaya, C., Higgs, D. (2001): The Influence Of Water Deficit On Vegetative Growth, Physiology, Fruit Yield And Quality In Eggplants. - Bulg. J. Plant Physiol. 27(3-4): 34-46.

[30] Korkmaz, A., Değer, Ö., Kocaçınar, F. (2015): Alleviation of water stress effects on pepper seedlings by foliar application of glycinebetaine. New Zealand Journal of Crop and Horticultural Science 43 (1) 18-31.

[31] Lattanzio, V., Lattanzio M.T.V., Cardinali, A. (2006): Role of Polyphenols in the Resistance Mechanisms of Plants Against Fungal Pathogens and Insects. Phytochemistry 37: 23-67. Publisher: Research Signpost, 37/661 (2), Fort P.O., Trivandrum-695 023, Kerala, India Editors: F. Imperato

[32] Li, H. B., Wong, C. C., Cheng, K. W., Chen, F. (2008): Antioxidant properties in vitro and total phenolic contents in methanol extracts from medicinal plants. - LWT - Food Science and Technology 41(3): 385-390.

[33] Li, Y., Schellhorn, H. E. (2007): New Developments and Novel Therapeutic Perspectives for Vitamin $C^{1,2}$. - The Journal of Nutrition 2171-2184. 
[34] Marín, A., Ferreres, F., Francisco, A., Barberán, T., Gil. M.,I. (2004): Characterization and Quantitation of Antioxidant Constituents of Sweet Pepper (Capsicum annuum L.). Journal of Agricultural and Food Chemistry 52(12): 3861-3869 DOI: 10.1021/jf0497915.

[35] Mitchell, J.P., Shennan, C., Grattan, S.R., May, D.M. (1991): Tomato fruit yield and quality under water deficit and salinity. - J. Amer. Soc. Hort. Sci. 116(2): 215- 221.

[36] Mohamed, H. I., Akladious, S. A. (2014): Influence of Garlic Extract On Enzymatic and Non Enzymatic Antioxidants in Soybean Plants (Glycine Max) Grown under Drought Stress. - Life Science Journal 11(3): 46-58.

[37] Nahar, K., Gretzmacher, R. (2002): Effect of water stress on nutrient uptake, yield and quality of tomato (Lycopersicon esculentum Mill.) under subtropical conditions. - Die Bodenkultur 53(1): 45-51.

[38] Nascimento, N.C., Fett-Neto, A.G. (2010): Plant secondary metabolism and challenges in modifying its operation: an overview. - Methods Mol Biol. 643: 1-13. doi: 10.1007/978-1-60761-723-5_1.

[39] Nunez Ramirez, F., Gonzalez Mendoza, D., Grimaldo Juarez, O., Diaz, L. C. (2011): Nitrogen Fertilization Effect on Antioxidants Compounds in Fruits of Habanero Chili Pepper (Capsicum chinense). - Int. J. Agric. Biol. 13(5): 827-830.

[40] Osuagwu, G. G. E., Edeoga, H. O. (2012): The influence of water stress (drought) on the mineral and vitamin content of the leaves of (Gongronema latifolium Benth). - Int. J. Med. Arom. Plants, ISSN 2249-4340. 2(2): 301-309.

[41] Öztekin, G. B. (2009): Aş1lı Domates Bitkilerinde Tuz Stresine Karşı Anaçların Etkisi (Doktora Tezi). - Ege Üniversitesi, İzmir. 290-316.

[42] Penella, C., Nebauer, S. G., Lopez-Galarza, S., San Bautısta, A., Rodriguez-Burruezo, A., Calatayud, A. (2014): Evaluation of some pepper genotypes as rootstocks in water stress conditions. - Hort. Sci. (Prague) 41(4): 192-200.

[43] Pereira, T. S., Lobato, A. K. S., Tan, D. K. Y., Costa, D. V., Uchôa, E. B., Ferreira, R. N., Pereira, E. S., Ávila, F. W., Marques, D. J., Guedes, E. M. S. (2013): Positive İnterference of Silicon on Water Relations, Nitrogen Metabolism, and Osmotic Adjustment in Two Pepper (Capsicum annuum) Cultivars Under Water Deficit. Australian Journal of Crop Science 7(8): 1064-1071.

[44] Reddy, A. R., Chaitanya, K. V., Vivekanandan, M. (2004): Drought-induced responses of photosynthesis and antioxidant metabolism in higher plants. - Journal of Plant Physiology 161: 1189-1202.

[45] Rontein, D., Basset, G., Hanson, A. D. (2002): Metabolic Engineering of Osmoprotectant Accumulation in Plants. - Metabolic Engineering 4: 49-56.

[46] Sağlam, A., Terzi, R., Nar, H., Saruhan, N., Ayaz, F. A., Kadığlu, A. (2010): Inorganıc And Organic Solutes In Apoplastic And Symplastic Spaces Contribute To Osmotic Adjustment Durıng Leaf Rollıng In Ctenanthe Setosa. - Acta Biologica Cracoviensia Series Botanica 52(1): 37-44.

[47] Shao, G. C., Wang, M. H., Yuan, M., She, D. L., Liu, N., Kumar, P. (2014): Growth and Comprehensive Quality Index of Tomato under Rain Shelters in Response to Different Irrigation and Drainage Treatments. Hindawi Publishing Corporation. - The Scientific World Journal 2014: 1-12. Article ID 457937.

[48] Sharma, P., Jha, A. B., Dubey, R. S., Pessarakli, M. (2012): Reactive Oxygen Species, Oxidative Damage, and Antioxidative Defense Mechanism in Plants under Stressful Conditions. - Journal of Botany Article ID 217037, 26 pages, http://dx.doi.org/10.1155/2012/217037

[49] Siddique Y. H., Ara G., Beg T., Afzal M. (2006): Effect of Vitamin C on Cyproterone Acetate İnduced Genotoxic Damage in Mice. - Research Journal of Biological Sciences 1(1-4): 69-73.

[50] Silva Sa F. V., Lima G. S., Santos J. B., Gheyi H. R., Anjos Soares L. A., Cavalcante L. F., Paiva E. P., Padua Souza L. (2016): Growth and physiological aspects of bell pepper 
(Capsicum annиum) under saline stress and exogenous application of proline. - African Journal of Biotechnology 15 (36): 1970-1976.

[51] Sroka, Z., Cisowski, W. (2003): Hydrogen peroxide scavenging, antioxidant and antiradical activity of some phenolic acids. - Food and Chemical Toxicology 41(2003): 753758.

[52] Stagnari F., Galieni A., Speca S., Pisante M. (2014): Water Stress Effects On Growth, Yield And Quality Traits Of Red Beet. - Scientia Horticulturae 165: 13-22.

[53] Subramanian, K. S., Santhanakrishnan, P., Balasubramanian, P. (2006): Responses of field grown tomato plants to arbuscular mycorrhizal fungal colonization under varying intensities of drought stress. - Scientia Horticulturae 107(3): 245-253.

[54] Tadesse T, Hewett EW, Nichols MA, Fisher KJ. (2002): Changes in physicochemical attributes of sweet pepper cv. Domino during fruit growth and development. - Sci. Horticult. 93: 91-103.

[55] Timpa, J. D., Burke, J. J., Quisenberry, J. E., Wendt, C. W. (1986): Effects of Water Stress on the Organic Acid and Carbohydrate Compositions of Cotton Plants. - Plant Physiol. 82: 724-728.

[56] Trovato, M., Mattioli, R., Costantino, P. (2008): Multiple Roles of Proline in Plant Stress Tolerance and Development. - Rendiconti Lincei 19(4): 325-346.

[57] Ünyayar, S., Keleş, Y., Çekiç, F. Ö. (2005): The antioxidative response of two tomato species with different drought tolerances as a result of drought and cadmium stress combinations. - Plant Soil Environment 51(2): 57-64.

[58] Vural, H., Eşiyok, D., Duman, İ. (2000): Kültür Sebzeleri (Sebze Yetiştirme). - Ege Üniversitesi Basımevi. Bornova. İzmir.

[59] Yıldırım O. (1996): Sulama Sistemleri 2. Tarımsal Yapılar ve Sulama Bölümü. - Ziraat Fakültesi. Ankara Üniversitesi. Yayın No: 1449, 354 p. Ankara.

[60] Yooyongwech, S., Theerawitaya, C., Samphumphuang, T., Chaum, S. (2013): Waterdeficit tolerant identification in sweet potato genotypes (Ipomoea batatas (L.) Lam.) in vegetative developmental stage using multivariate physiological indices. - Scientia Horticulturae 162 (2013): 242-251.

[61] Zheng, W., Wang, S.Y. (2001): Antioxidant Activity and Phenolic Compounds in Selected Herbs. - J. Agric. Food Chem. 49: 5165-5170. 